\title{
Determination of Physiochemical Properties and Lactic Acid Bacteria Presence in Ackee (Blighia sapida) Fruit
}

\author{
Lawal, R.T. ${ }^{1}$; Oyeleke, G.O. ${ }^{1}$; Ishola, A.D ${ }^{1}$ and Akinsuroju, M.O. ${ }^{2}$ \\ ${ }^{1}$ Osun State Polytechnic, Iree, Nigeria, Department of Science Laboratory Technology \\ ${ }^{2}$ Josephy Ayo Babalola University, Ikeji-Arakeji, Nigeria, Department of Biological Sciences
}

\begin{abstract}
This study covers proximate analysis and Antimicrobial activities of cell free extract of lactic acid bacterial from Blighia sapida fruit (Ackee). The proximate analysis of Blighia sapida were determined using standard methods which varied in contents. The proximate analysis of the sample were ash content $(6.10 \pm 0.03 \%)$, moisture content $(5.43 \pm 0.12 \%)$, fat content $(14.60 \pm 0.02 \%)$, crude fibre content $(25.12 \pm 0.02 \%)$, protein content $(14.19 \pm 0.09 \%)$ and

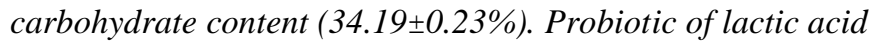
bacteria isolated from Blighia sapida (Ackee) were identified as Lactobacillus leshmanni, and Lactobacillus acidophilus, with Streptomycin sulphate as control. Antimicrobial activities of the lactic acid isolated were determined by the agar well diffusion methods against pathogenic bacteria: Escherichia coli, Staphylococcus aureus, Xanthomonas sp, Pseudomonas aeruginosa, Salmonella typhi and Bacillus subtilis. The zone of inhibition ranged from $3 \mathrm{~mm}$ to $25 \mathrm{~mm}$ and control ranged from $23 \mathrm{~mm}$ to $30 \mathrm{~mm}$. Lactobacillus acidophilus displayed high antimicrobial activity compared with Lactobacillus leshmanni showing its probiotic potential of lactic acid bacteria use for food supplement.
\end{abstract}

Keywords-Blighia sapida, probiotic, L. leshmanni, L. acidophilus, proximate analysis.

\section{INTRODUCTION}

Ackee arils have been reported to have comparable proximate composition to many known legumes and oil seeds (Ekue et al., 2010; Akintayo et al., 2002; Howele et al., 2010). However, Ackee arils have little commercial and nutritional significance in the West African sub-region.

The ripe fruit arils are eaten fresh, dried, fried, roasted or made into sauce or soup in some parts of West Africa (Ekue et al., 2010).

Various parts of the Ackee tree are employed in traditional medicine for the treatment of fever, malaria, internal hemorrhage, dysentery, yellow fever, diabetes and constipation in West Africa. The roots, bark, leaves, capsules and seeds were identified in the treatment of 22 diseases in Benin (Ekue et al., 2010). Consumption of Ackee roots bark extract exerted significant hypoglycemic effect on the normoglycemic albino rats (Saidu et al., 2012). However, limited information exists on the health beneficial components of the arils.

The fruit produces lather in water and is therefore used for laundering purpose in some West Africa countries (Saidu et al., 2012). The extract of the flowers is used as cologne while the pulverized bark is mixed with grounded hot peppers and rubbed on the body as stimulant. Probiotic are defined as live microorganism which when consumed in adequate amounts as part of the diet, may play an important role in respiratory, immune and gastrointestinal functions and have a significant effect on the clearance of infectious diseases in children and lactose intolerance (FAO/WHO, 2001). The objectives of this study is to determine the proximate composition and assess antimicrobial activities of lactic acid bacteria against pathogenic microorganisms.

\section{MATERIALS AND METHODS}

Fruit used were obtained from Masifa-lle, Ejigbo Local Government, Osun State western part of Nigeria, The fresh sample was sun dried for 3 days and was later oven-dried for another 2 days at $60^{\circ} \mathrm{C}$ which was immediately blended and was carefully packed in air tight polythene bag and kept in a refrigerator at $4^{\circ} \mathrm{C}$ until further analysis.

\section{Proximate Analysis of Blighia sapida}

Moisture content was determined at $105^{\circ} \mathrm{C}$ using air oven, ash content was determined at $550^{\circ} \mathrm{C}$ with muffle furnace while crude protein, fat and crude fibre were determined according to the procedures of AOAC (2000). 
Cultural and Morphological Characteristics of Bacteria from Blighia sapida

Lactic acid bacteria were isolated from the fruits using DeMann Rogosa Sharpe (MRS) agar and incubated for 24 hours. After incubation, the distinct bacterial colonies on the cultured plates were examined for colonial characteristics such as colour, shape, size, elevation, surface and edges. The growth pattern of lactic acid bacteria (LAB) in MRS broth after incubating at $37^{\circ} \mathrm{C}$ and $45^{\circ} \mathrm{C}$ for 24 hours was examined (Dave and Shah, 1996).

Antimicrobial Activity of the LAB Isolates from Blighia sapida

Antimicrobial activities of the sample were determined by the agar well diffusion method. $24 \mathrm{~h}$ broth culture of the test isolates such as Escherichia coli, Staphylococcus aureus, Xanthomonas sp Pseudomonas aeruginosa, Salmonella typhi and Bacillus subtilis, were prepared. Two milliliter of the broth was added to molten nutrient agar separately and allowed to solidify under laminar flow. Size $8 \mathrm{~mm}$ cork borer was used to carve uniform wells on the surface of the dry seeded plates. $0.5 \mathrm{ml}$ of each cell-free extract was introduced into each well separately with the aid of needles and syringes before incubation. The plates were incubated at $37^{\circ} \mathrm{C}$ for 24 h. Zones of inhibition were measured with the aid of digital Vernier caliper and recorded appropriately and control plates were using Streptomycin sulphate.

\section{RESULTS AND DISCUSSION}

The moisture content of Blighia sapida $(5.43 \pm 0.12 \%)$ was low compared to that of Fallon et al., (2014) who reported $(8.39 \pm 0.25 \%)$ for tree-ripened Ackee. It was also a little bit low to the Akintayo et al., (2002) that obtained (6.8\%) for Ackee pulp and seed flours. Differences in reported moisture content could be due to different methods of ripened. However it was obviously lower than $10 \%$ moisture content limit recommended for storage stability of flours (Oladele and Oshodi, 2008). Ash content of $(6.10 \pm 0.03 \%)$ was higher than the $(4.9 \%)$ reported by Ouattara et al., (2010). Fat content of $(14.60 \pm 0.02 \%)$ is considered similar to $(14.0 \pm 0.60 \%)$ reported for tree ripened Blighia sapida (Fallon et al., 2014). Fat is important in diets because it promotes fat soluble vitamin absorption. Crude fibre of Ackee fruit was very high $(25.12 \pm 0.02 \%)$ compared with $(16.14 \pm 0.04 \%)$ reported by Oyeleke et al., (2013) for Ackee pulp and pulp oil. Low crude fibre is undesirable as it could cause constipation and such diets have been associated with diseases. Crude protein content of $(14.19 \pm 0.09 \%)$ was higher compared to $(5.89 \%)$ obtained by Ureigho and Ekeke (2010) but low in comparison with protein rich foods such as soybeans, cowpea, pigeon peas, melon, pumpkin and gourd seeds ranging between (23.1-33.0\%) (Olaofe and Sanni, 1988) and (World Health Organization 2007). The United States recommended daily allowance (RDA) specified that, protein should be consumed at a minimum of $0.45 \mathrm{~g}$ and maximum of $0.8 \mathrm{~g}$ per kilogram of an ideal body weight per day and this requirement can be supplemented with the protein content from this sample. Carbohydrate content had higher value $(34.19 \pm 0.23 \%)$ than that of Chrysophyllum albidum with $(10.38 \%)$ reported by Ureigho and Ekeke (2010). Carbohydrates are one of the essential nutrients that provide energy to human body.

Table.1: Proximate Compositions of Blighia sapida (\%)

\begin{tabular}{ll}
\hline Parameter & $\begin{array}{l}\text { Value } \pm \\
\text { S.D }\end{array}$ \\
\hline Ash content & $6.10 \pm 0.03$ \\
\hline Moisture content & $5.43 \pm 0.12$ \\
\hline Fat content & $14.60 \pm 0.02$ \\
\hline Crude fibre content & $25.12 \pm 0.02$ \\
\hline Protein content & $14.19 \pm 0.09$ \\
\hline Carbohydrate content (By difference) & $34.19 \pm 0.23$ \\
\hline $\mathbf{N}=2$ & \\
\hline
\end{tabular}




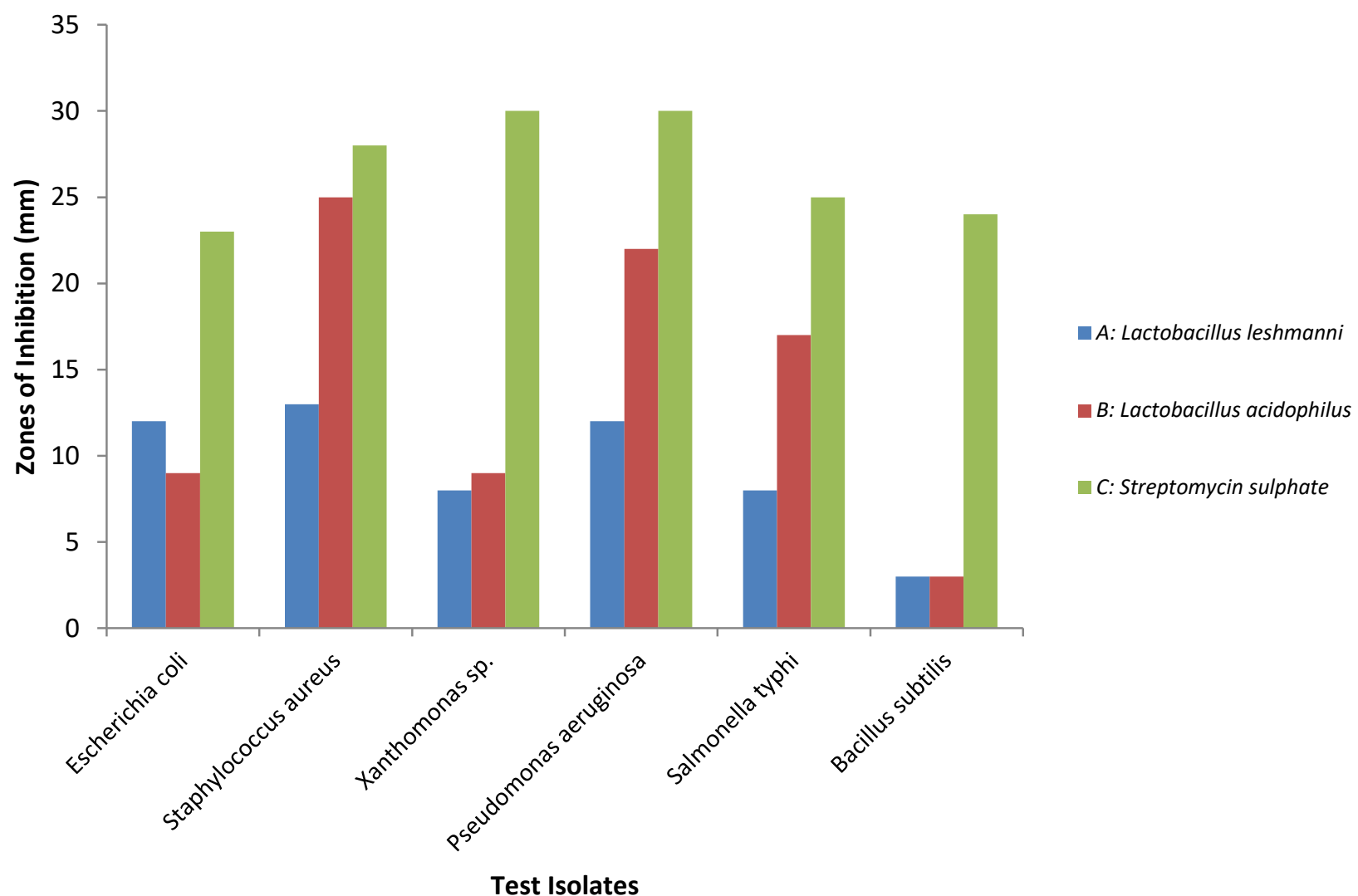

Fig.1: Antimicrobial Activity of Cell Free Extract of Lactic Acid Bacterial Against Pathogenic Organisms

The two Lactobacilli isolated from Blighia sapida were tested for inhibitory potential against Escherichia coli, Staphylococcus aureus, Xanthomonas sp, Pseudomonas aeruginosa, Salmonella typhi and Bacillus subtilis and demonstrated the ability to inhibit all pathogenic bacteria and Streptomycin sulphate used as control for the pathogenic organisms mentioned above. The Lactobacillus acidophilus had highest inhibitory value $25 \mathrm{~mm}$ in Staphylococcus aureus and both Lactobacillus acidophilus and Lactobacillus leschmanni were lower $3 \mathrm{~mm}$ in inhibitory of Bacillus subtilis while control Streptomycin sulphate had higher values between $30 \mathrm{~mm}-23 \mathrm{~mm}$ shown in (figure 1). Staphylococcus aureus is a Gram positive opportunistic human pathogen it is one of important bacteria isolated from burn patients and is a common cause of commonly and hospital acquired infections involving skin infections and septicemia (Revazishvili et al., 2006). The inhibitions of test bacteria by Lactobacilli in Blighia sapida were between 3 mm-25 mm (figure 1). The Lactobacillus leschmanni and Lactobacillus acidophilus of lactic acid bacteria inhibited the growth of test organisms and control had higher inhibition between $23 \mathrm{~mm}$ - $30 \mathrm{~mm}$. It has higher values $3 \mathrm{~mm}-25 \mathrm{~mm}$ than the report obtained for the inhibition value of Mango pulp (2.64 mm) (Ravi et al., 2011).

\section{CONCLUSION}

The lactic acid bacteria isolated from Blighia sapida fruit had high inhibition of pathogenic bacteria.

\section{REFERENCES}

[1] Akintayo, E.T., Adebayo, E.A., and Arogundade, L.A. (2002). Chemical Composition, Physicochemical and Functional Properties of Ackee (Bilghia sapida) Pulp and Seed Flours. Food Chemistry, 77: 333-336.

[2] AOAC (2000), "Official Methods of Analysis", Association of Official Analytical Chemists, Washington DC.

[3] Ekue, M .R. M., Sinsin, B., Eyog-Matig, O. and Finkeldey, R. (2010). Uses, Traditional Management, Perception of Variation and Preferences in Ackee (Blighia sapida K.D. Koenig) Fruit Traits in Benin: Implications for Domestication and Conservation. Journal of Ethnobiology and Ethnomedicine, 6(12), 114. 
[4] Falloon, O’Neil Calvin, Gail S.H. Baccus-Taylorb, and Donna A. Minott. (2014). A Comparative Study of the Nutrient Composition of Tree-Ripened Versus RackRipened Ackees (Blighia sapida). The West India Journal of Eng. 36(2):69-75.

Food Standards Agency (UK). Retrieved 2007-02-19.

[5] Howele, O., Bobelé, N., Théodor, D. and Seraphi, K. C. (2010). Nutritional Composition Studies of Sun Dried Blighia sapida (K. Koenig) Aril from Côte d'Ivoire. Journal of Applied Biosciences 32, 1989-1994.

[6] Dave, R.I. and Shah, N.P. (1996). Evaluation of Media for Selective Enumeration of Lactobacillus acidophilus \& Bifidobacterium sp. J. Dairy Sci., 79: 1529-1536.

[7] Nielsen, S.S. (2003). Food Analysis Laboratory Manual. (3rd ed.). Kluwer Academic Plenum Publishers, New York.

[8] Olaofe, O. and Sanni, C. O. (1988). Mineral Contents of Agriculture Product. Food Chem. 30:73-79.

[9] Oladele, E.P. and Oshodi, A.A. (2008). Effect of Fermentation on Some Chemical and Nutritive Properties of Berlandier Nettle Spurge (Jatropha cathartica) and Physic Nut (Jatropha curcas) Seeds. Parkistan J. Nutr. 7(2): 292-296.

[10] Ouattara, H., Niamke, B., Dally, T. and Kati-Coulibaly, S. (2010). Nutritional Composition Studies of Sun Dried Blighia sapida (K. Koenig) aril from Cote d'Ivoire. Journal of Applied Bioscience. 1989-1993.

[11] Oyeleke, G.O., Oyetade, O.A., Afolabi Fatai and Adegoke, B.M. (2013). Nutrients, Antinutrients and Physicochemical Compositions of Blighia Sapida Pulp and Pulp Oil (Ackee Apple). IOSR Journal of Applied Chemistry. 4(1): 05-08.

[12] Ravi, V., Prabhu, M. and Subramanyam, D. (2011). Isolation of Bacteriocin Producing Bacteria from Mango Pulp and its Antimicrobial Activity. $J$. Microbiol. Biotech. Res., 1 (2): 54-63.

[13] Revazishvili, T., Bakanidze, L., Gomelauri, T., Zhyenti, E., Chanturia, G., Kekelidze, M., Rajanna, C., Kreger, A., Sulakvelidze, A. (2006). Genetic Background and Antibiotic Resistance of Staphylococcus aureus Strain Isolated in the Republic of Georgia. Journal of Clinical Microbiology 44(10): 3477-3483.

[14] Saidu A.N., Mann A. and Onuegbu C.D. (2012). Phytochemical Screening and Hypoglycemic Effect of Aqueous Blighia sapida Root Bark on Normoglycemi albino Rats, British Journal of Pharmaceutical Rearch., 2(2): 89-97.

[15] Ureigho, U.N and Ekeke, B.A. (2010). Nutrient Values of Chrysophyllum albidum Linn African Star Apple as a Domestic Income Plantation Species. 50-56. 